\title{
Evaluation of landslide hazard level on spatial pattern of Tanah Datar Regency
}

\author{
Indang Dewata ${ }^{1 *}$, Iswandi Umar $^{1}$ \\ ${ }^{1}$ Chemistry Department State Universitas Negeri Padang, Airtawar Padang City West Sumatera Province (25114)
}

\begin{abstract}
Natural disasters have caused much harm to human life. Migration through disaster based planning is one way to minimize risks. The purpose of this study is to evaluate the level of landslide hazard in the planning of spatial pattern in Tanah Datar Regency. To determine the landslide hazard level using the scoring method through the overlay of a thematic map. Indicators used are slope, rainfall, soil type, geology, landform, and land use. Furthermore, evaluation of landslide hazard on spatial planning is determined by overlaying hazard level maps with land use plans in spatial pattern planning. The results showed that the $26 \%$ landslide hazard rate was a high danger level, $46 \%$ moderate hazard level, and $38 \%$ low hazard level. In addition, hazard level evaluation of spatial patterns resulted in approximately $37.3 \%$ planning for residential areas having high hazard levels. Therefore, it is necessary to revise the pattern of regional space and include the element of disaster in the planning of spatial pattern.
\end{abstract}

\section{Introduction}

Indonesia has a humid-tropical climate with high rainfall intensity. Torrential rain is a natural phenomenon happens suddenly in a relatively short time at a certain place, so that landslide may occur. Landslides can cause the loss of life of the residents who lived nearby (Sitorus, 2006) (Harnawir, 2012). According to Utoyo et al. (2001) and Canuti et al. (2003), landslides have not only caused by high rainfall, but change the characteristics of the region and the human activities can also cause a landslide. Currently, landslide often occurs and destroying settlements as well as other facilities and infrastructure. This led to the loss of property and the soul of the inhabitants who lived in the area, so that the necessary realignment of settlements into the area of the non-avalanche (Virdin, 2001; Syahrin, 2003; Syriac and Marisa, 2005; and Martono et al., 2005).

Rapid development has led to a change in land use patterns, where the waking spaces are increasingly dominating and pushing the natural spaces to change function (Pribadi et al., 2006). In addition, Aaron (1992) and Kustiawan (1997) explain that changes in land use patterns result in fluctuations in the carrying capacity of land resources, causing landslide disasters. Buol et al. (1980) and Darmawijaya (1990) explain that landslide is essentially caused by the inability of the soil to hold the load on it because the soil has already degraded the soil properties. Law on Disaster Management No. 24/2007 and National Disaster Management Authority - BNPB (2012) explains that disaster-prone is a geological, biological, hydrological, climatological, geographic, social, cultural, political, economic, and technological condition of an area for a certain period of time that reduces ability to prevent, dampen, reach readiness, and reduce the ability to respond to adverse impacts of certain hazards. Efforts that can be done in order to prevent or minimize the adverse effects of the flood disaster do to mitigation.

Local Disaster Management Authority (BPBD) of Tanah Datar Regency recorded an increase of landslide disaster both from the frequency of affected area in the period 2000-2017. One form of mitigation that can be done to minimize the impact of flood risk by determining the landslide-prone zone in Tanah Datar regency. Tanah Datar based on physical characteristics has a very vulnerable area for landslide disaster, among others: a) the morphology of the area about 55 percent is relatively flat area $(<27 \%)$; b) about $70 \%$ of Limapuluh Kota Regency of primary forest area switches to secondary forest area; c) increasing rainfall intensity in upstream watershed areas; and d) the development of the wake area. Based on the above background, the purpose of this study is to determine the evaluation of landslideprone areas in Tanah Datar regency. In addition, this study will also determine the level of vulnerability of settlements and spatial patterns in Tanah Datar Regency.

\section{Research method}

\subsection{Location and period of study}

This research was conducted at Tanah Datar Regency of West Sumatera Province. Geographically the research location is located at longitude $100^{\circ} 18^{\prime} \mathrm{LE}-100^{\circ} 50^{\prime} \mathrm{LE}$ and latitude $0^{\circ} 18^{\prime} \mathrm{LS}-0^{\circ} 40^{\prime} \mathrm{LS}$. This study has been conducted during June - October 2017.

Corresponding author: indangdewata@yahoo.com 


\subsection{Sources of data}

The type of data in this study is categorized into two types, primary data and secondary data. Primary data is generated from measurement and collection from the field, while secondary data is obtained from official documents, information, and records from various relevant agencies. Table 1 presents the matrix types and data sources.

\subsection{Technic analysis of data research}

The landslide-prone zone in Tanah Datar Regency is determined by using the geographic information system approach that is the overlapping/overlay method. In overlay analysis using Art GIS 10.1 software. The landslide zoning is determined by considering six indicators ie soil type, slope, geological type, and geomorphic. The logical process, rainfall, and use (Table
2. ). Each indicator is described in several sub-indicators with different values.

Furthermore, for the determination of interval class using following equation:

$$
\mathrm{I}=\frac{c-b}{k}
$$

where:

I: large distance interval class

c: highest score

b: lowest score

$\mathrm{k}$ : number of desired classes

The highest total score of landslide-prone rate (TRL) is 4.1 while the lowest total score is 1.1 . The landslideprone zone is divided into three classes: high-risk zones, medium-prone zones, and low-risk zones. Table 3 . presents the interval class of landslide-prone zone.

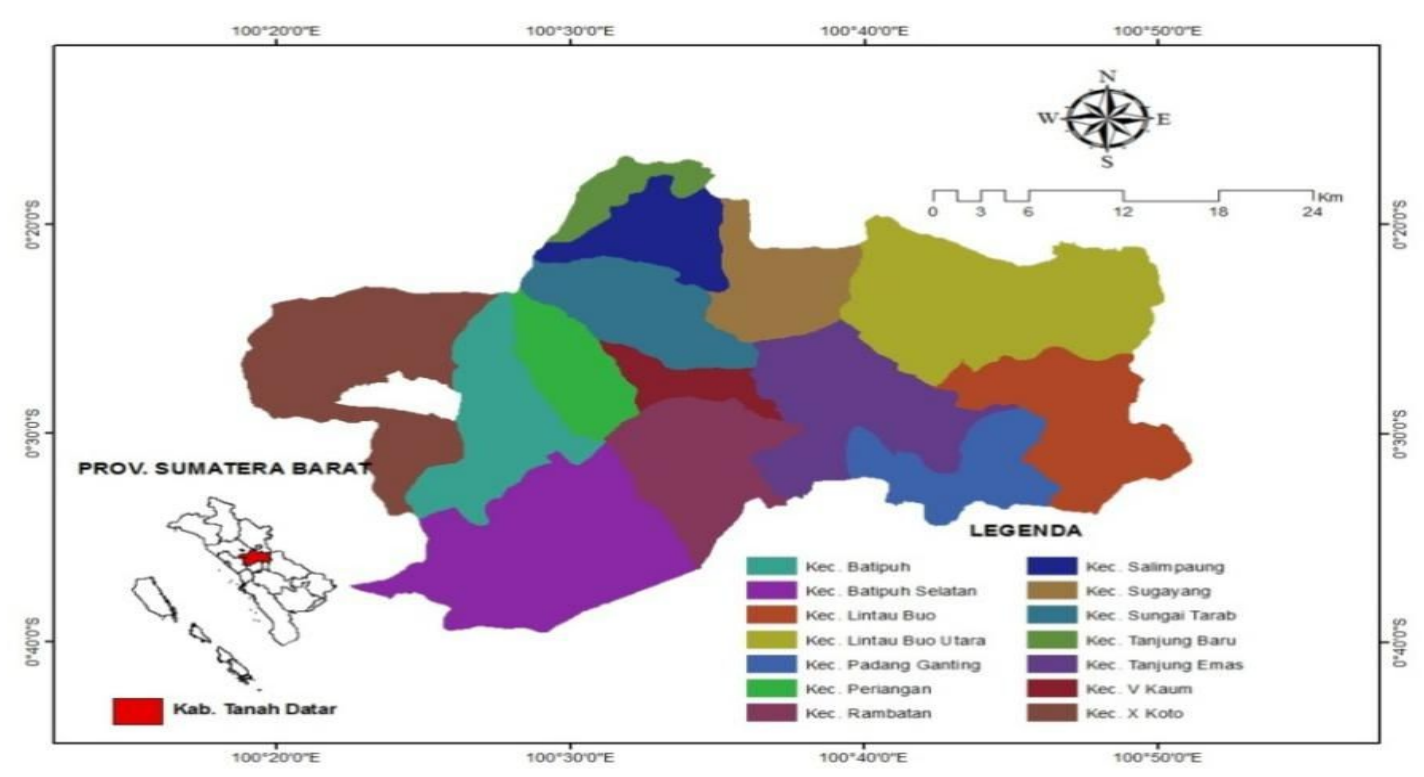

Fig. 1. Research location

Table 1. Matrix types and sources of research data

\begin{tabular}{cll}
\hline No & Source data type & \multicolumn{1}{c}{ Source } \\
\hline 1. & Map Slopes & Image Shuttle Radar Topography Mission (SRTM) 1 Arc Second \\
2. & Land Map & Map of Soil Type (PPT) Bogor 1990 scale 1: 250.000 \\
3. & Land System & Map of the Regional Physical Planning Program for Transmigration 1990 at scale 1: \\
& & 250.000 \\
4. & Rainfall Data & BMKG rainfall data Sicin period 1975-2017 \\
5. & Geological Map & Bandung Geological Agency year 2007 scale 1; 250,000 \\
6. & Landsat & Landsat 7 + ETM land cover in 2016 and corrected with Quick Bird image 0.65m in \\
& & 2010. \\
7. & Elevation & Image Shuttle Elevation Radar Topography Mission (SRTM) 1 Arc Second \\
\hline
\end{tabular}


Tabel 2. Indicator prone to landslides

\begin{tabular}{|c|c|c|c|}
\hline Indicators / weighting & Sub Indicators & Value & Score \\
\hline \multirow[t]{3}{*}{ Types of soil $(0,10)$} & Andosol & 1 & 0,1 \\
\hline & Latosol & 2 & 0,2 \\
\hline & Podzolic & 3 & 0,3 \\
\hline \multirow[t]{5}{*}{ Slope $(0,25)$} & $0-8 \%$ (Flat) & 1 & 0,25 \\
\hline & 8-14 \% (Sloping) & 2 & 0,5 \\
\hline & $15-25 \%$ (Somewhat Steep) & 3 & 0,75 \\
\hline & $25-40 \%$ (Steep) & 4 & 1 \\
\hline & $>40 \%$ (Very Steep) & 5 & 1,25 \\
\hline \multirow[t]{4}{*}{ Geomorphological $(0,10)$} & Denudasional & 2 & 0,2 \\
\hline & Fluvial & 1 & 0,1 \\
\hline & Karst & 3 & 0,3 \\
\hline & Volcanic & 4 & 1 \\
\hline \multirow[t]{10}{*}{ Geological $(0,10)$} & Aluvium & 1 & 0,1 \\
\hline & Rocks of fire & 3 & 0,3 \\
\hline & Intrusion rocks & 3 & 0,3 \\
\hline & Metamorf rocks & 3 & 0,3 \\
\hline & Limestone rocks & 2 & 0,2 \\
\hline & Branin Formation & 3 & 0,3 \\
\hline & Kuantan Formation & 3 & 0,3 \\
\hline & Ombilin Formation & 3 & 0,3 \\
\hline & Sangkarewang Formation & 3 & 0,3 \\
\hline & Tuhur Formation & 3 & 0,3 \\
\hline \multirow[t]{6}{*}{ Rainfall (mm/year) $(0,20)$} & $2500-3000$ & 1 & 0,2 \\
\hline & $3000-3500$ & 2 & 0,4 \\
\hline & $3500-4000$ & 3 & 0,6 \\
\hline & $4000-4500$ & 4 & 0,8 \\
\hline & $4500-5000$ & 5 & 1 \\
\hline & $>5000$ & 6 & 1,2 \\
\hline \multirow[t]{6}{*}{ Land use $(0,05)$} & Forest & 1 & 0,05 \\
\hline & Plantation & 2 & 0,1 \\
\hline & Settlement & 4 & 0,2 \\
\hline & Rice fields & 3 & 0,15 \\
\hline & Field & 2 & 0,1 \\
\hline & Moor & 3 & 0,15 \\
\hline
\end{tabular}

\section{Results and discussion}

Christiadi (2006) said landslides can be affected by several factors, like geological conditions, hydrology, topography, climate, and land use. Areas with steep slope characteristics will be prone to landslides when high rainfall factors and uncontrolled land use. Tanah Datar regency has a relatively undulating area, 55 percent of its territory with slopes of the category somewhat steep to very steep. Only 20 percent area with relatively flat slopes. Based on the rainfall level the research area has an average rainfall of 3000-3500 $\mathrm{mm} /$ year. Fig. 2. presents a map of slopes and rainfall in Tanah Datar territory.

Based on geology, Tanah Datar Regency is largely formed by volcanic rocks. Mount Merapi in the west has an important role in the geological formation process of largely Tanah Datar Regency. Semangko's fractures shape changes and reshuffle the area. Geomorphologically, the denudation affects the process of forming the region. Fig. 3. presents geological and geomorphological map of Tanah Datar Regency.

Fig. 4. shows the land type map and land use of Tanah Datar Regency. Based on the soil type most of the land is andosor, where the soil andosor is a young soil. The type of soil andosol has dominated characteristics by clay content and volcanic sand, making it very easy to happen avalanches. Furthermore, based on land use Tanah Datar Regency is still dominated by the use of forest areas. But an increase in the number of people will push for the expansion of the wake area. 


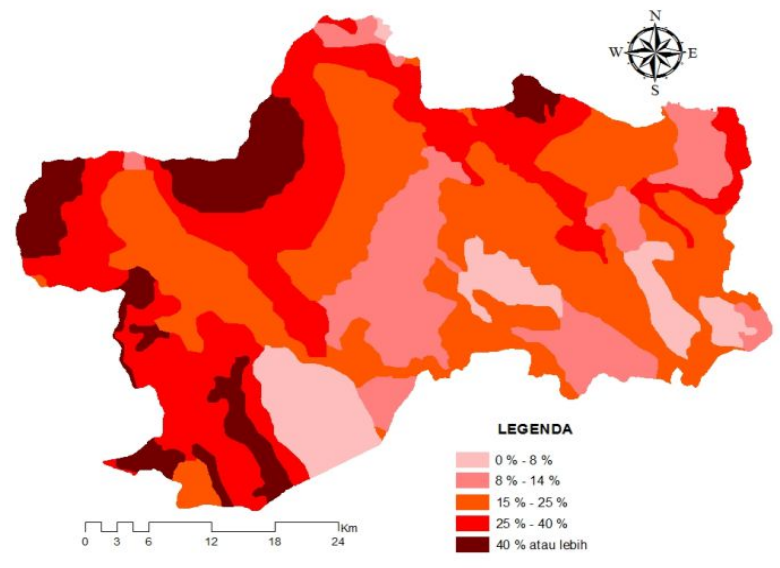

(a)

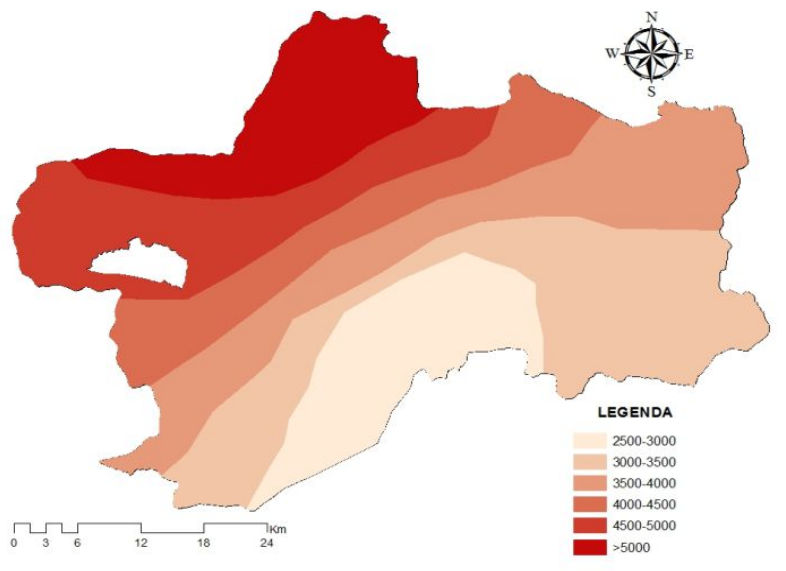

(b)

Fig. 2. Map of slopes (a) and rainfall (b) of Tanah Datar Regency

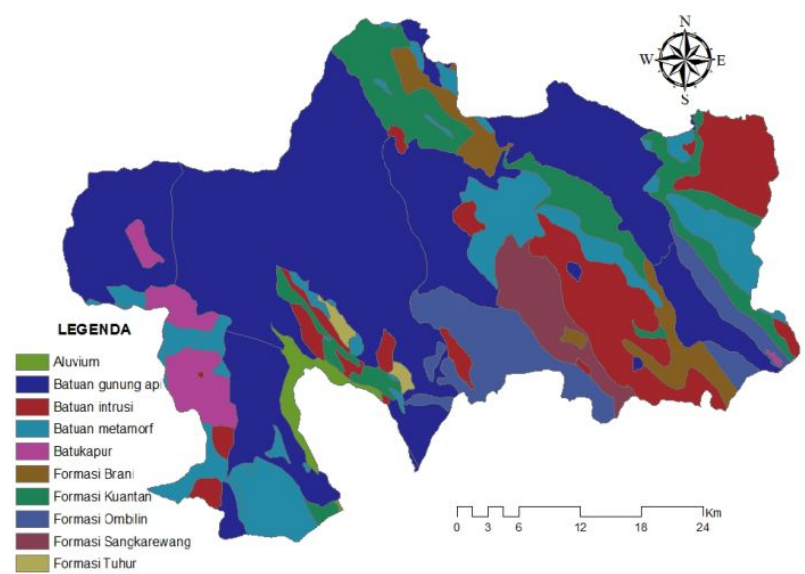

(a)

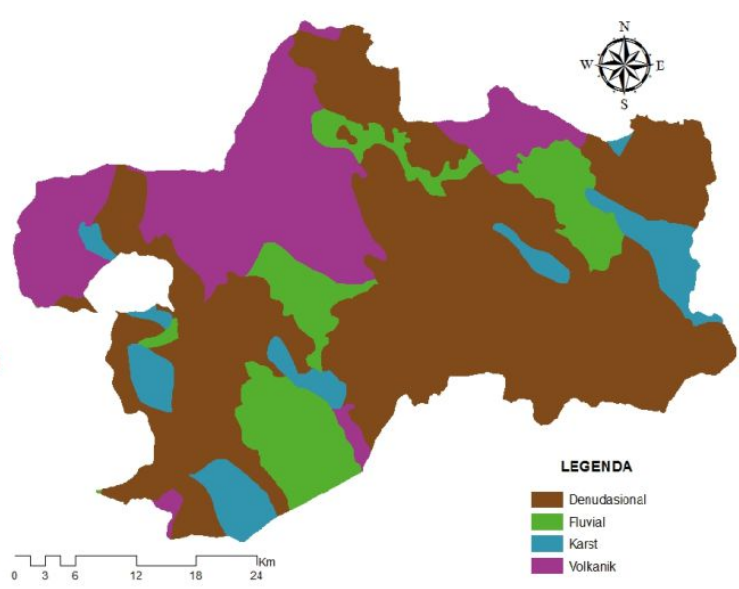

(b)

Fig. 3. Geological map (a) and geomorphological map (b) of Tanah Datar Regency

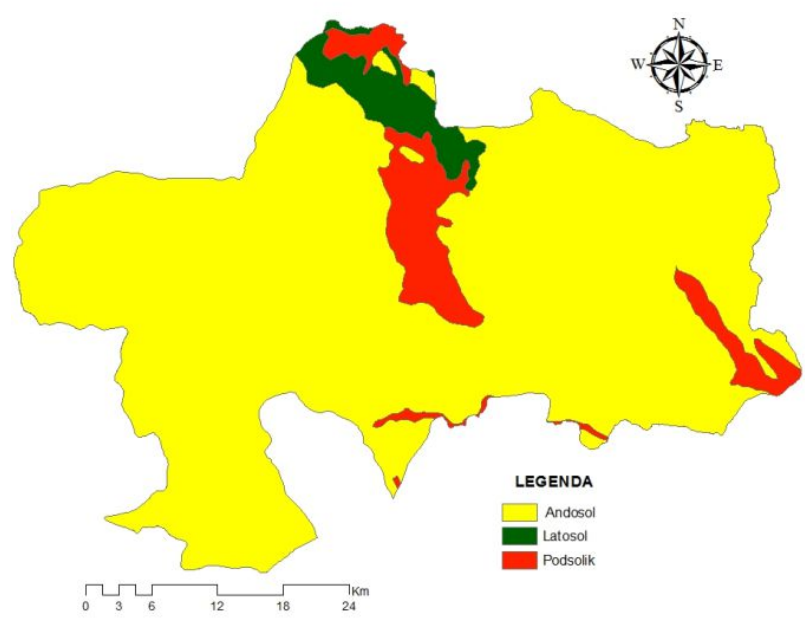

(a)

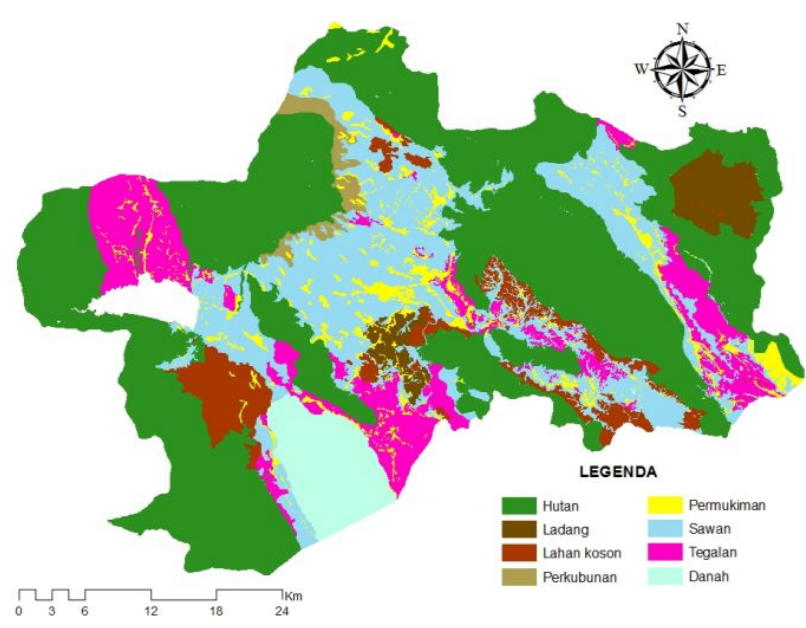

(b)

Fig. 4. Land type map (a) and land use map (b) of Tanah Datar Regency 
The results showed that in Tanah Datar Regency there was 35.6 percent of areas with high landslide vulnerability, 54.4 percent of medium vulnerability, and the remaining 10 percent were low vulnerable zones. This can mean that Tanah Datar Regency is a major area prone to landslide disaster. Zoning of landslide-prone areas in Tanah Datar is presented in Fig. 5.

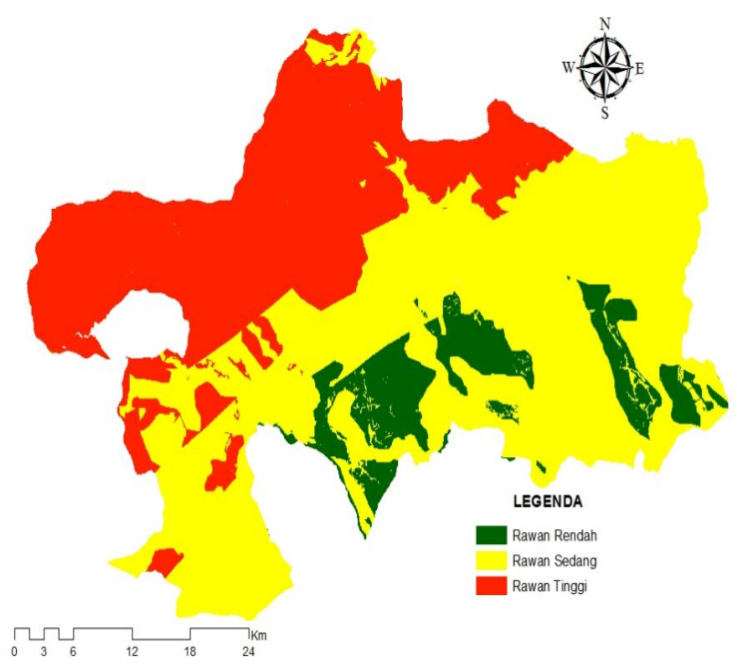

Fig. 5. Map of landslide-prone zones in Tanah Datar District

Settlement areas in Tanah Datar always run every year. Percentage of settlements growth (2000-2016) is 1.3 percent each year. The growth of residential areas is directly proportional to the increase in population. Based on data from the local bureau of statistics (2016), the percentage of population growth in the research area is 0.33 percent/year. Umar et al (2017) said the utilization of land cannot be separated from human life. Land use is directly proportional to the growing number of people on earth. The more human numbers inhabit the earth's surface, the higher the need for land use. While the available land to accommodate human needs is limited. Sadyohutomo (2008) added that the limitations of land that can be utilized for human life cause the happening of conflicts between land users. Muata, Ali (2012) said that the increase in population causes the human use of natural resources without regard to the ability and carrying capacity of the environment. As a result, the quality of the environment and natural disasters has decreased.

Fig. 6. is an overlay between landslide-prone zones with land use for residential areas in 2016 in Tanah Datar Regency indicating that 28.23 percent of residential areas are in highly vulnerable zones of landslides, about 63.36 percent of medium-prone areas of settlement, and around The remaining 8.4 percent are in low-risk zones. Based on the above analysis can be interpreted that a part residential area has a high level of vulnerability to landslide disaster.

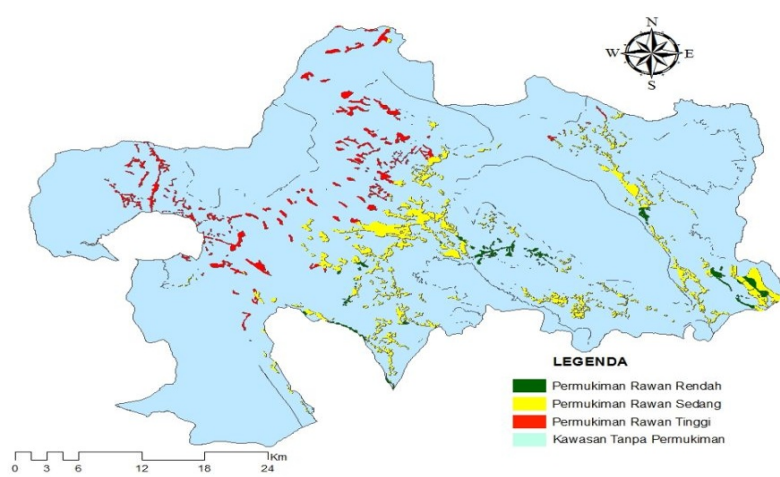

Fig. 6. Overlay between landslide-prone zones with land use for residential areas in 2016 in Tanah Datar Regency

\section{Conclusion}

Tanah Datar Regency is an area with relatively rugged topography with high rainfall. The characteristic constellation of the area has an impact on landslide disaster. Tanah Datar Regency has about 35.6 percent of the area with high vulnerability level to landslide disaster. Settlement area in the period 2000-2016 has a development of settlement area of about 1.6 percent/year. Increasing the need for settlement land has an impact on the area in the zone prone to landslide. About 28.23 percent of the settlements are in high-risk zones. Therefore, it is necessary to mitigate and limit licensing efforts for the development of zones in landslide-prone zones.

Acknowledgments to PPKLH UNP, UNP Postgraduate Environmental Science Program, and S2 Master of Geography Education FIS UNP who has helped and facilitated the implementation of this research.

\section{References}

1. Sitorus, S.R.P. 2006. Fixed Coverage Land Development as Control of Risk Factors for Erosion and Landslide Disasters. Paper. Spatial Planning Workshop as a Means to Minimize the Potential of Landslide Disasters. Jakarta. 7 Maret 2006

2. Utoyo, B.S., E. Anwar, I.M. Sandy, R.S. Saefulhakim, dan H. Santoso. 2001. Linkage Analysis between Regional Growth and Changing Patterns of Land Use Structure. Postgraduate Program. 24: 159-162

3. Canuti, P., N.Casagli, and R. Fanti. 2003. Landslide Hazard for Archaeological Heritage: The Case of Tharros in Italy. Landslides News. 14/15: 40-43

4. Virdin J.W. 2001. Understanding the Synergies between Climate Change and Desertification. UNDP

5. Syahrin, A. 2003. Legal Arrangements and Sustainable Housing and Settlement Development Policies. Pustaka Bangsa Press 
6. Suryani, R.L. dan A. Marisa. 2005. Aspects Affecting Urban Settlement Problems. Program Studi Arsitektur. Fakultas Teknik USU. Medan

7. Martono, D.N., Surlan, dan B.T. Sukmana. 2005. Remote Sensing Data Application to Support Spatial Planning in Indonesia. http://io.ppi.jepang.org/article

8. Pribadi, D.O., D. Shiddiq, dan M. Ermyanila. 2006. Model Changes in Land Cover and Factors Affecting It. Journal of Environmental Technology. Pusat Pengkajian dan Penerapan Teknologi Lingkungan. 7: 35-51

9. Harun, U.R. 1992. The Dynamics of Land Use in West Java 1970-1990. Jurnal PWK. 3: 48-53

10. Kustiawan, I. 1997. Agricultural Land Conversion Problems and Their Implications for Regional Spatial Planning. Case Study: Pantura Region of West Java. Jurnal PWK. 8: 49-60

11. Buol, S.W., F.D. Hole., and R.J. Cracken. 1980. Soil Genesis and Classification. Second Edition. The Iowa State University Press. Amess

12. [RI] Republik Indonesia. 2007. Republic of Indonesia Law Number 24 Year 2007 concerning Disaster Management.

13. [BNPB] National Disaster Management Agency. 2012. Regarding the General Guidelines for Disaster Risk Assessment Number 2 of 2012.

14. [BNPB] National Disaster Management Agency. 2017. Regional Disaster Statistics.

15. Zain, A.F.M. 2002. Distribution, Structure dan Function of Urban Green Space in Southeast Asian Mega-Cities with Special Reference to Jakarta Metropolitan Region (JABOTABEK). Doctoral Degree Program. Department of Agricultural and Environmental Biology Graduate School of Agricultural and Life Sciences. The University of Tokyo. Japan

16. Hermon, D. 2017. Disaster Geography. Rajawali Press. Jakarta

17. [BPS] Tanah Datar Statistics Agency. 2016. Land Flat in Numbers

18. Umar, I., Widiatmaka, Pramudya, B., dan Barus, B., 2017Land Suitability Evaluation for Settlements with the MCE Approach in Padang City. Jurnal PSL. 2 (2): 84-95

19. Sadyohutomo, M. (2008). City Management and Reality and Challenge Areas. Bumi Aksara Publisher. Jakarta.

20. Muta'ali, L., 2012. Environmental Support for Regional Development Planning. Geography Faculty Publishing Agency (BPFG) Gadjah Mada University, Yogyakarta. 